\title{
Effect of Exchange Rate Volatility on Return on Assets of Consumer Goods Manufacturing Companies Listed In Nigeria
}

\author{
Ezenwa, Anthony C. (Post-Graduate Student) ${ }^{1}$, Ogbebor, Peter I. (Ph.D.) ${ }^{2}$, Alalade, Yimka S. A. (Ph.D) ${ }^{3}$ \\ 1,2,3 Department of Finance, School of Management Sciences, Babcock University, Ilishan-Remo, Ogun State, Nigeria
}

\begin{abstract}
The financial performance of consumer goods firms in Nigeria is constrained by a weak macroeconomic framework with persistent exchange rate volatility, multiple exchange rate windows and forex restrictions, and distortionary activities by the central bank. Thus, persistent exchange rate volatility exposes the companies to external risks because their projected revenue and costs, alongside profit margin and earnings per share, are affected. Hence this study examined the effect of exchange rate volatility on return on assets of consumer goods manufacturing companies listed in Nigeria between the periods of 2010 to 2019.
\end{abstract}

The study engaged an ex-post facto research design. A purposive sampling technique was used to select a sample size of fourteen (14) consumer goods firms from the listed firms. The study used panel data, panel regression models estimated was in respect to the fixed-effect model and random effect model, Hausman test indicated the appropriate model, while the exchange rate volatility (ERV) was computed using GARCH approach. The inferences were drawn at $1 \%, 5 \%$, and $10 \%$.

The findings of the study showed that exchange rate volatility was negative and had statistically significant effect on return on assets $[$ coefficient $=-\mathbf{0 . 4 5 4} ; \mathbf{P}-$ value $=0.013$ ]. Firm's Size was found to be negative and had statistically significant effect on return on assets at $1 \%$ level $[$ coefficient $=-0.057 ; P$ - value $=$ $0.000]$. Leverage had negative and statistically significant effect on return on assets [coefficient $=-\mathbf{0 . 0 8 9} ; \mathbf{P}-$ value $=0.091$ ]

The study concluded that exchange rate volatility has a significant influence on return on assets. The study recommended that the monetary authorities should employ various policies to steer the exchange rate downward. This will help boost local firm return on assets and at the same time increase firms' productivity.

Keywords: Exchange rate Volatility, Financial Performance, Firms Size, Leverage, Return on Assets

\section{INTRODUCTION}

$\mathrm{R}$ eturn on assets is a proxy for financial performance. Financial performance evaluations have been mainly used in forecasting the future performance of companies and ranking them in the stock market which investors put into consideration before investing (Amar, 2017). Financial performance enhances the assessment of business goals and assists organizations to plan effectively to achieve steady growth in earnings. Umero and Udo (2015) emphasized that many manufacturing firms fail because of poor financial management and a lack of prudent financial evaluation and assessment. In developed economies, manufacturing companies play a pivotal role in the growth and development of a nation. Darell and West (2018) emphasized the financial performance of manufacturing companies in the United State of America. The authors noted that in terms of financial performance, China, the United State of America, and Japan comprise 48 percent have seen renewed growth over the years. Furthermore, in China, manufacturing companies contribute twenty-seven (27) percent of China's overall national output, which accounts for 20 percent of the world's manufacturing output. Haile, Getacher, and Tesfay (2014) stated that the financial performance of manufacturing companies in the United State of America is of paramount importance since manufacturing firms play an important role in stimulating entrepreneurial growth and reflects operational efficiencies of management in inducing growth in earnings.

Agubata and Odubuasi (2018) stated that the performances of manufacturing companies in Nigeria are majorly affected by macro-economic factors. Among the macro-economic factors is the exchange rate volatility which directly affects the financial performances of manufacturing companies at the levels of economic exposure, transaction exposure, and translation exposure. The effect of exchange rate volatility has a long history in any economy. One of the reasons for the failure of Bretton Woods's agreements can be traced to the impact of foreign exchange (Agubata \& Odubuasi, 2018). Most developed nations have in one way or the other put mechanisms in place to guide against instability in their exchange rate movement or stability. This implies that the impacts of exchange rate volatility have dire consequences on the economies of countries whether developed or developing. Despite the efforts pulled together by the regulatory authorities to revitalize the consumer goods manufacturing companies, the Nigerian manufacturing sector continues to witness unsteady growth in its financial position coupled with distress and failure occasioned by an unstable macroeconomic environment. Oyedokun, Tomomewo, and Owolabi (2019) opined that quite a good number of manufacturing companies in Nigeria have ceased to operate, and more prominent companies have acquired many or at best, merged with other more prominent manufacturing companies. Some have relocated their operational base to neighboring countries 
(Abdul \& Isiaka, 2015). Few manufacturing companies that are still operating within the Nigerian market experiences a high cost of production caused by extreme working conditions, unsteady power, high-loan cost, and conversion standard vulnerability (Sangosanya, 2011). To fill this important void in the literature, this research work studies the effect of exchange rate volatility on return on assets of consumer goods companies listed in Nigeria.

\section{Objectives of the Study}

To determine the effect of exchange rate volatility and moderating variables on return on assets (ROA) of consumer goods manufacturing companies listed in Nigeria.

\section{Research Question}

What is the effect of exchange rate volatility and moderating variables on the return on assets (ROA) of consumer goods manufacturing companies listed in Nigeria?

\section{Research Hypothesis}

$\mathrm{H}_{01}$ : exchange rate volatility and moderating variables have no significant effect on return on assets (ROA) of consumer goods firms listed in Nigeria

\section{REVIEW OF RELATED LITERATURE}

\section{Return on Assets}

Return on Assets falls within the domain of financial performance measures and tracks a firm ability to generate income based on its assets. The ratio excludes non-operating income and donations. ROA is expected to be positive as a reflection of the profit margin of the manufacturing firm, otherwise, it reflects the loss. Babalola (2014) explained return on assets as an indicator of how much profit a company generated for each one naira in assets. It also can be used as a way to gauge the asset intensity of a business. ROA suggests that companies with higher amounts of assets should be able to earn a higher level of income; it is an indicator of how profitable a company is concerning its total assets.

The ROA figures show investors how effectively the company is converting the money it has invested into income. The higher the ROA number, the better, because it implies that the company is earning more money on its investment. Additionally, the return on asset measures how effectively a company can earn a return on its investment in assets. In other words, ROA shows how efficiently a company can convert the money used to purchase assets into net income or profits. Since all assets are either funded by equity or debt, some investors try to disregard the cost of acquiring the assets in the return calculated by adding back interest expense in the formula. It only makes sense that a higher ratio is more favorable to investors because it shows that the firm is effectively managing its asset to produce a greater amount of net income (Casu, Girardone, \& Molyneux, 2006). Although ROA provides useful information about firms' financial performance, it is not the most important to equity holders. The problem with ROA is that it excludes some assets from the total assets off-balance sheet items (for instance, assets acquired through a lease) thereby understating the value of assets. This can eventually create a positive bias where ROA is overstated in the evaluation of firm financial performance; nonetheless, it has always been a very good measure of firm financial performance.

\section{Exchange Rate Volatility}

The foreign exchange market is characterized by volatility and uncertainty which makes the prediction of future prices difficult. These fluctuations pose a threat to importers and exporters engaging in international business as they are naturally exposed to currency risks (Allayannis, Ihuing \& Weston, 2016). Manufacturing companies are vulnerable to potential gains and losses due to changes in the values of their raw materials and purchase prices that are denominated in foreign currencies. Thus, exportation and importation activities expose these firms to foreign exchange risks.

Exchange rate volatility refers to the unpredictable movement of exchange rates in the global foreign exchange market. Thus, exchange rate volatility indicates the degree of variability of the exchange rate from time to time. Exchange rate fluctuation does not only affect economic growth but also the performance of firms (Ayobami, 2019). For instance, exchange rate depreciation increases the cost of imported capital goods for manufacturing firms, and this results in a fall in domestic investment.

Moffett, Stonehill, and Eiteman (2017) categorized exchange rates into four types which include; the fixed exchange rate which is controlled by the government and dependent on a country's reserves for a specific period. The managed floating exchange rate is the rate based on the demand and supply of specific currencies under certain interactions of the government. Freely floating rate is the exchange rate that fully relies on the force of demand and supply at an open market, without any government interaction.

\section{Leverage}

Biddle, Hilary, and Verdi (2009) defined Leverage as total obligations allocated by total assets. The concept of using total debts is to avoid the conflicting relationship of long-term debt or short-term debt with Leverage (Nwaobia, Kwarbai \& Ogundajo, 2016).

\section{Firm Size}

There are three fields of order as indicated by writing which goes about as the primary determining factors of firm size namely, organizational, technological, and institutional theories (Kumar, Rajan \& Zingales, 1999). This categorization is subject to if the theory is based on the process of control, environmental influences, or production functions (Zadeh \& Eskandari, 2012). This categorization is subject to if the theory is based on the process of control, environmental influences, or production functions (Zadeh \& Eskandari, 2012). 


\section{THEORETICAL REVIEW}

\section{International Fisher Effect Theory}

The theory was authored by Irving Fisher in 1930. The International Fisher Effect is the international counterpart of the Fisher Effect. It can be seen as a combination of the generalized version of the Fisher Effect and the relative version of the Purchasing Power Parity. The International Fisher Effect is based on the assumption that the changes in the spot rate of exchange between two currencies will be equal to the differences in their nominal interest rates.

Furthermore, the International Fisher Effect theory proposes that higher interest rates will devalue currencies due to the higher nominal rates that replicate higher anticipated inflation. The International Fisher's Theory establishes connections between variances in the interest rate of two nations and their conforming differences in inflation, to the level that high inflation rates countries would possess nominal interest rates that are higher than the ones with lower inflation rates (Ebiringa \& Anyaogu, 2014). The theory contends that real interest rates among countries are equal because of the arbitrage opportunities possibility which normally arises in the form of capital flows between financial markets. Real interest rate equality denotes that the higher interest rate country ought to possess an inflation rate that is higher which, sequentially, establishes the ideal currency value decrease of the country in a precise period (Lagat \& Nyandema, 2016).

In support of the International Fishers Effect model, Lagat and Nyandema (2016) noted that the International Fisher Effect model expands on the Fisher Effect, suggesting that because nominal interest rates reflect anticipated inflation rates and currency exchange rate changes are driven by inflation rates, then currency changes are proportionate to the difference between the two nations' nominal interest rates.

The International Fisher Effect has been criticized on the basis that it is applicable in the long run because average annual deviation as a measure for long-term validity tends towards zero. The maximum annual deviation was however too large to support the theory in the short run. Furthermore, Robinson and Warburton (2005) disputed the validity of the International Fisher Effect and argued that the possibility to earn a higher interest return would be eroded in the medium term by the appreciation of the currency with the lower interest rates relative to the currency with the higher interest rate. They concluded that superior returns could be earned and therefore argued that International Fisher Effect does not hold empirically. The International Fisher Effect Model is relevant to this study as it provides a link between interest rate and the exchange rate which implies that the changes in the spot rate of exchange between two currencies will be equal to the differences in their nominal interest rates.

\section{Stock Oriented Model}

The stock-oriented model was developed by Branson and Frankel in 1983. These models show that exchange rates as a function of supply and demand for financial assets such as stocks and bonds. This approach suggests that an increase in stock prices induces investors to demand more domestic assets and thereby causes an appreciation in the domestic currency, implying that stock prices influence exchange rates. Thus, the appreciation of the domestic currency attracts more foreign capital and investments into the domestic market, which then leads to further currency appreciation.

In support of the stock-oriented model, Agubata and Odubuasi (2018) asserted that a stock price increase would trigger massive capital inflows, thus, exchange rates would appreciate owing to an increase in the demand for domestic currency. In other words, the exchange rate is determined by the demand and supply of financial assets.

Critics of the stock-oriented model such as Richards, Simpson, and Evans (2009) criticized the stock-oriented model on the ground that it failed to consider international capital movements. The authors noted that the stock-oriented model is not applicable. The author noted that stock oriented model is only applicable in the developmental stages of the firm but in the early stages of the firm, the effect of exchange rate volatility on the financial performance of firms tends towards the flow-oriented model (Cerra \& Saxena, 2010). This theory is important to this study as it provides an alternative explanation suggesting that there is a link between stock prices and exchange rates prevailing in the economy at a particular period.

\section{Theoretical Framework}

The International Fisher Effect Model is relevant to this study as it provides a link between interest rate and the exchange rate which implies that the changes in the spot rate of exchange between two currencies will be equal to the differences in their nominal interest rates.

\section{Empirical Review}

Several authors have examined exchange rate volatility and the financial performance of firms in both developed and developing economies using different methodologies. BajoRubio, Berke, and McMillan (2020) investigated exchange rate volatility in the eurozone. The empirical results showed no clear-cut evidence on the impact of exchange rate volatility on the exports of the countries analyzed, suggesting that financial markets are developed enough so that exchange rate volatility does not hinder the exports.

Obisesan, Ogunsanwo, Odunayo, and Oluwayemisi (2019) studied the effect of foreign exchange management on economic growth in Nigeria from 1987 to 2017. The result of their study found that the real exchange rate has a positive and significant effect on economic growth; inflation rate revealed a negative and insignificant effect on economic growth; the degree of openness indicated a positive and insignificant effect on economic growth and lastly, foreign direct investment displayed positive and statistically insignificant effect on economic growth in Nigeria. The study concluded 
that foreign exchange management has a positive and insignificant effect on economic growth in Nigeria. The authors recommended that investors should consider fluctuations in other macroeconomic variables rather than fluctuation in the exchange rate market to guide their decisions to ascertain where to direct investments for profit maximization. The study further suggested that the government and the monetary authorities should design policies and programs that will curtail the rising inflation rate thereby encouraging investors to invest in Nigeria.

Adjei (2019) examined the effect of exchange rate volatility on economic growth in Ghana. The investigation covered the period between 1983 and 2010. The variables of concern were five in all which included Exchange rate volatility, Trade Openness, GDP per capita, Physical capital stock, and Human capital stock. The exchange rate volatility variables generated were then used in the growth determinant function. The study employed Autoregressive Distributed Lag Approach to analyze the relationship between exchange rate volatility and economic growth in Ghana. From the estimation results, the conclusion drawn was that exchange rate volatility has a significant negative effect on economic growth during the period both in the short and long run. This is because of the high risk in investing hence discouraging international trade and growth. The study recommended that policymakers should aim at stabilizing the exchange rate as that will encourage investors and improve productivity and trade hence good economic performance.

Osho and Efuntade (2019) investigated the effect of exchange rate fluctuation on performance evaluations of multinational companies in Nigeria. The objective of the study was to examine how foreign exchange affects the financial performance of multinational companies in Nigeria. The Ordinary Least Square (OLS) regression analysis was carried out, to determine the effect of exchange rate fluctuation on the performance of multinationals in Nigeria. Hence, return on assets (ROA) was regressed on Exchange rate (EXCHr), Inflation rate (INFr), and Interest rate (INTr). The overall regression results showed that exchange rate fluctuation has a significant effect on the performance of multinational companies in Nigeria. As a result of this, it was concluded that exchange rate instability affects the operations of companies in Nigeria vis-à-vis international trade with other countries of the world.

Harley (2018) examined the impact of exchange rate fluctuations on a firm's performance in Nigeria. In their study, seven research questions were formulated which led to the test of seven hypotheses. The major objective of the study was to empirically investigate the impact of exchange rate fluctuations on the return of the asset. The study used the descriptive and ordinary least square methodology. The scope of the study was from 2012 to 2016 on panel data. The findings of the study indicated that the exchange rate plays a significant impact in Return on assets as most of the banks are involved in exchange rate transactions. The regression result further showed that there is a positive relationship between Return on Asset and exchange rate.

Orji, Ogbuabor, Okeke, and Anthony-Orji (2018) studied the impact of exchange rate $(\mathrm{EXCH})$ movements on the financial performance of manufacturing companies in Nigeria over the period 1981-2016. Time series data and ordinary least square (OLS) estimation technique were employed in their study to address the specific objective. The variables analyzed were return on asset, exchange rate, manufacturing GDP (MGDP), government capital expenditure, foreign direct investment (FDI), credit to the private sector, and value of imports. The result revealed that exchange rate movements hurt the return on assets of manufacturing companies in Nigeria. Specifically, the findings showed that exchange rate, government capital expenditure (GCEXP), imports, and foreign direct investment were positively related to manufacturing GDP, while credit to the private sector was negatively related. The study recommended that the apex bank should keep a closer watch on the exchange rate and formulate up-to-date policies that will ultimately enhance exchange rate stability. This will largely contribute to the development of the manufacturing sector in the short and long run.

Mahat, Dahir, Sahabuddin, and Mahi (2017) investigated the influence of exchange rate volatility on the financial performance of agriculture firms in Malaysia. The authors employed the GMM dynamic panel techniques, wavelet coherence technique, and $\operatorname{GARCH}(1,1)$ for 2001 and 2015. The findings showed that the volatility of the exchange rate of Malaysian Ringgit (RM) hurts the financial performance of agriculture firms in Malaysia. The ARME and AVA demonstrated a positive impact on the financial performance at $1 \%$ significance level for the full sample. The findings also revealed that financial performance, exchange rate, consumer price index, and interest rate movements while using the wavelet coherence.

Musa (2016) studied the effect of foreign exchange rate volatility on financial performance measured as return on asset of local oil marketing companies in Kenya. The results indicated that there exists no significant relationship between inflation and financial performance with a p-value of 0.392 . In the same regard, the study revealed that there was no significant relationship between performance and interest rates with a p-value of (.497). Further, the study showed no significant relationship between foreign exchange volatility and return on asset with a p-value of (.306). The study further recommended that oil marketing companies should consider adopting Domestic or Multi-domestic strategies which are suitable for the local economic environment other than applying global strategies that may be affected by forex volatility. The study also observed and recommended blending of foreign exchange rate risk management strategies that are best suited for the oil marketing companies.

Kelilume (2016) investigated the effects of volatility clustering in the exchange rate on the firm's performance in Nigeria, using cross-sectional data for the most active twenty 
(20) companies listed on the Nigerian Stock Exchange. The empirical investigation developed three dynamic panel models that account for heterogeneities among the companies and it extends recent research by allowing international investors and corporations to base their investment decisions on the exchange rate volatilities between the Nigerian Naira and selected home country currencies. The results showed that exchange rate volatility has significant negative impacts on return on assets. Overall, the study suggested that the higher the exchange rate volatility, the lesser the firm efficiency and performance.

Similarly, Okolo, Ugwuanyi, and Okpala (2016) evaluated the effect of exchange rate volatility on the financial performance of manufacturing companies in Nigeria. The flow and stock market theories of exchange rate determination were adopted considering macroeconomic determinants such as the balance of trade, trade openness, and net international investment. Furthermore, the influence of changes in the parallel exchange rate, official exchange rate, and real effective exchange rate was modeled on the manufacturing sector output. Vector autoregression techniques and vector error correction mechanism were adopted to explore the macroeconomic determinants of exchange rate fluctuation in Nigeria and to examine the influence of exchange rate volatility on the manufacturing sector output in Nigeria. The exchange rate showed an unstable and volatile movement in Nigeria which had a negative effect on the return on asset of manufacturing companies in Nigeria. Official exchange rate significantly impacted on return on asset of manufacturing companies in Nigeria and shock to previous manufacturing sector output caused sixty-one percent $(61 \%)$ of the fluctuation in the manufacturing sector output in Nigeria. Trade balance, trade openness, and net international investments did not significantly determine the exchange rate in Nigeria. However, own shock accounted for ninety-five (95\%) of the variation of exchange rate fluctuation in the short-run and long-run.

Osundina, Osundina, Jayeoba, and Olayinka (2016) examined the effect of exchange rate fluctuation on bank performance in Nigeria covering ten years between 2005 and 2014. They measured exchange rate fluctuation by return average annual values of US dollar to Naira for the ten years while exchange rate volatility was tested using (ARCH LM test) proving its fluctuating nature. Hausman Test was conducted for fixed and random effect preferred option. The study found that exchange rate fluctuation had an insignificant effect on banks' profitability using return on assets (ROA) as a measure while exchange rate fluctuation had a significant negative effect on banks' liquidity using a loan to deposit ratio (LDR) as a measure. The study concluded that the effect of exchange rate fluctuation on banks' performance is subjective on the specific measure of performance used in the research. However, the results suggest that further depreciation in the value of the naira will lead to a fall in the liquidity position of the banks.
Ishimwen and Ngalawa (2015) investigated the impact of exchange rate volatility on South Africa's manufacturing exports and financial performance of manufacturing companies in the United States of America for the period of 1990Q1 to 2014Q1. The study employed the EGARCH model to measure exchange rate volatility, and the ARDL bounds tests as developed by Pesaran, Shin, and Smith to determine the long-run and short-run effects of exchange rate volatility on the country's manufacturing exports. The study also carries out a Granger causality test between real exchange rates and exports of manufactured products. The findings of the study showed that an increase in exchange rate volatility has a significant positive effect on manufacturing exports in the long run. However, the results are insignificant in the short run. It is also found that real exchange rates Granger cause manufacturing exports. Manufacturing exports, however, do not Granger cause real exchange rates.

Majok (2015) studied the effects of exchange rate fluctuations on the financial performance of forty-three (43) commercial banks operating in Kenya from 2002 to 2014. The study examined the return on asset (ROA) of the forty-three (43) commercial banks as a performance indicator and used a descriptive research design and ANOVA to investigate the significance of the effects of changes in the exchange rate on the financial performance of commercial banks. The study used secondary data collected from the banks' consolidated financial statements and the Central Bank of Kenya. The results revealed a weak negative relationship between exchange rate fluctuations and the financial performance of commercial banks in Kenya.

\section{METHODOLOGY}

This study adopted an ex-post facto research design. Ex post facto design was employed to identify a natural impetus for specific outcomes without actually manipulating the independent variable. The adoption of this research design was based on the fact that the study intends to use historic data obtained from the relevant publications and as such the data already are in existence. Secondary data will be extracted from the financial statements of the selected consumer goods manufacturing companies.

\section{The population of the Study}

The population of the study consists of all the twenty (20) consumer goods manufacturing companies in Nigeria listed on the Nigerian stock exchange as of $31^{\text {st }}$ December 2019.

\section{Sample Size and Sampling Technique}

Based on the population of the study, a sample size of fourteen (14) consumer goods firms were selected from the listed firms. The sampling technique was purposive sampling technique which is a direct way of obtaining the sample size in which the author only considers typical cases which may quickly and easily provide the required information. The selected firms are stated below Cadbury Nigeria PLC, Champion Breweries PLC, Livestock Feeds PLC, Nigeria 
Flour Mills PLC, Guinness PLC, International Breweries PLC, NASCON PLC, Nigeria Breweries PLC, NESTLE PLC, Nigerian Northern Flour Mills PLC, PZ PLC, Unilever Nigeria PLC, UNION DICON PLC, and Vita Foam PLC

\section{Model Specification}

The model in this study followed the work of Agubata and Odubuasi (2018) where they examined the effect of exchange rate fluctuations on the financial performance of manufacturing companies in the food, beverages, and tobacco sector. Specifically, the financial performance variable was defined as Return on Asset (ROA), while exchange rate volatility was captured as the average annual exchange rate of naira to dollars.

Thus, the model is specified as:

Functional

$\mathrm{Y}=f(\mathrm{X})$

$\mathrm{X}=$ Exchange rate volatility $(\mathrm{ERV})$

$\mathrm{Y}=$ Financial performance $(\mathrm{FP})$

$\mathrm{Z}=$ Firm Size and Leverage

$\mathrm{y}_{1}=$ Return on assets (ROA)

$\mathrm{x}_{1}=$ Exchange rate volatility $(\mathrm{ERV})$

$\mathrm{z}_{1}=$ Firm Size $(\mathrm{FSZ})$

$\mathrm{z}_{2}=$ Leverage $(\mathrm{LEV})$

$\mathrm{ROA}_{\mathrm{it}}=f\left(\mathrm{ERV}_{\mathrm{it}}+\mathrm{FSZ}_{\mathrm{it}}+\mathrm{LEV}_{\mathrm{it}}\right)$

Where;

ERV - Exchange rate volatility

FSZ- Firm size

LEV- Leverage

Consequently, the econometric form, the models are:

$\mathrm{ROA}_{\mathrm{it}}=\beta_{0}+\beta_{1} \mathrm{ERV}_{\mathrm{it}}+\mathrm{FSZ}_{\mathrm{it}}+\mathrm{LEV}_{\mathrm{it}}+\mathrm{e}_{\mathrm{it}-}$ model (1)

Where:

$\beta=$ Parameter estimates

$\mathrm{e}=$ Error term

$\mathrm{i}=$ Cross sectional data

$\mathrm{t}=$ time series data

\section{RESULT AND DISCUSSION}

\section{Descriptive Analysis}

Table 1 presents the descriptive result for the variables used in this study. The variables are Return on Asset (ROA), Exchange rate volatility (ERV), Firm Size (FSZ), and Leverage (LEV).
Table 1: Descriptive Result

\begin{tabular}{|c|c|c|c|c|c|}
\hline \multirow{2}{*}{ Variable } & Obs & Mean & Std. Dev. & Min & Max \\
\cline { 2 - 6 } & & & & & \\
\hline ROA & 140 & 0.108 & 0.101 & -0.134 & 0.392 \\
\hline ERV & 140 & 0.032 & 0.032 & 0.004 & 0.095 \\
\hline FSZ & 140 & 17.279 & 1.865 & 12.082 & 19.995 \\
\hline LEV & 140 & 0.599 & 0.158 & 0.263 & 1.115 \\
\hline
\end{tabular}

Source: Author's Computation, 2021. Note: ROA represents Return on Asset, ERV represents Exchange rate volatility, FSZ represents Firm Size, LEV represents Leverage of the Firms.

As in Table 1, the Return on Asset (ROA) which is the ratio of Profit before Interest and Taxation to the total asset of the firms takes a value between -0.134 and 0.392 with an average of 0.108 and a standard deviation of 0.101 . This suggests that the firms' aggregate mean is 0.108 indicating that on average; the firms were able to generate about $10.8 \%$ profit relative to their total asset even though the minimum and maximum values show that the firms earn varying ROA (including negative) during the period of this study.

Furthermore, Exchange Rate volatility (ERV) had an average value of 0.032 with a minimum and maximum of 0.004 and 0.095 and a standard deviation of 0.032 . The values showed the amount of uncertainty related to the size of changes in the average Exchange Rate of Naira to Dollar. The average value of 0.032 is relatively small indicating that the exchange rate of Naira to Dollar doesn't change dramatically during the period of this study.

The Firm Size (FSZ) proxied by the natural log of Total Asset ranges between 12.082 and 19.995 with an average of 17.279 and a standard deviation of 1.865. With the standard deviation value of 1.865 and the mean value of 17.279 (approximately 18 ), it is safe to say that the selected firms' assets are relatively the same. Thus, the firms are similar in terms of size.

The average Leverage of the Firms (LEV) measured as the ratio of debt to a total asset of the Firms is 0.599 with minimum and maximum values of 0.263 and 1.115 respectively and a standard deviation of 0.158 . The minimum and maximum values depict that the leverage of the firms relatively varies during the period of this study.

\section{Correlation Matrix}

The results of the correlation analysis carried out to check the degree of associations especially among the explanatory variables are presented in Table 2 below.

Table 2: Correlation Matrix

\begin{tabular}{|c|c|c|c|c|}
\hline & ROA & ERV & FSZ & LEV \\
\hline & & \multicolumn{3}{|l|}{} \\
\hline ROA & 1 & \multicolumn{3}{|l|}{} \\
\hline ERV & -0.191 & 1 & & \\
\hline FSZ & 0.160 & 0.037 & 1 & \\
\hline LEV & -0.182 & 0.070 & 0.145 & 1 \\
\hline
\end{tabular}

Source: Author's Computation, 2021. Note: ROA represents Return on Asset, ERV represents Exchange rate volatility, FSZ represents Firm Size, LEV represents Leverage of the Firms. 
As in Table 2, the associations among the explanatory variables are generally weak. According to the result, correlations between Return on Assets (ROA), Exchange rate volatility (ERV), Firm Size (FSZ), and Leverage of the Firms (LEV) are $-0.191,0.160$, and -0.182 respectively. The correlation coefficients for Exchange rate volatility (ERV), Firm Size (FSZ), and Leverage of the Firms (LEV) are 0.037 and 0.070 respectively. While the correlation between FSZ and LEV is 0.145 . This means that all these variables except ERV) are positively correlated except ERV and LEV.

\section{Regression Analysis}

\section{GARCH $(1,1)$ Model}

To estimate the volatility in this study, GARCH $(1,1)$ was employed. The GARCH $(1,1)$ employed was consistent with extant literature. The estimated parameters and their corresponding coefficient values are presented in Table 3 below.

Table 3: GARCH $(1,1)$ Model

\begin{tabular}{|c|c|}
\hline GARCH Model & \\
\hline & Mean Model \\
\hline$c$ & -0.00026 \\
\hline$\alpha$ & Variance Model \\
\hline$\beta$ & $0.4206^{* * *}$ \\
\hline$\omega$ & $0.4992^{* * *}$ \\
\hline Log Liklihood & 0.000002 \\
\hline & 314.75 \\
\hline ARCH test (Sig.) & $0.36(0.482)$ \\
\hline
\end{tabular}

Source: Author's Computation, 2021. Note: e represents mean model constant, $\alpha$ represents ARCH term, $\beta$ represents GARCH term and $\omega$ represents variance model constant. $* * * \mathrm{p}<0.01, * * \mathrm{p}<0.05, * \mathrm{p}<0.1$.

From the result in Table 3, the lags of the squared residual from the mean equation (the ARCH term) and forecast variance (the GARCH term) are significant at $1 \%$ levels. In addition, they are seen to be positive indicating that lags of the squared residuals from the mean equation and forecast variance are positively related to the current volatility condition (conditional variance). Generally, the sum of the coefficients of ARCH and GARCH terms are less than one (0.9198), implying a desirable value that indicates high persistence of volatility shock.

Estimation Result of exchange rate volatility, moderating variables, and return on asset

Table 4: Exchange Rate Volatility, moderating variables and Return on Asset

\begin{tabular}{|c|c|c|c|}
\hline$(1)$ & $(2)$ & \multirow{2}{*}{ Variable } & $(3)$ \\
\cline { 1 - 1 } Pooled & Random & & Fixed \\
\hline & & & \\
\hline$-0.585^{* *}$ & $-0.538^{* * *}$ & \multirow{2}{*}{ ERV } & $-0.454^{* *}$ \\
\hline$(0.249)$ & $(0.190)$ & & $(0.179)$ \\
\hline
\end{tabular}

\begin{tabular}{|c|c|c|c|}
\hline$[0.020]$ & [0.005] & & [0.013] \\
\hline $0.011^{* *}$ & $-0.015^{*}$ & \multirow{3}{*}{ FSZ } & $-0.057 * * *$ \\
\hline$(0.004)$ & $(0.008)$ & & $(0.012)$ \\
\hline$[0.015]$ & {$[0.061]$} & & {$[0.000]$} \\
\hline$-0.126 * *$ & $-0.103^{*}$ & \multirow{3}{*}{ LEV } & $-0.089^{*}$ \\
\hline$(0.051)$ & $(0.053)$ & & $(0.052)$ \\
\hline$[0.014]$ & {$[0.052]$} & & [0.091] \\
\hline 0.020 & $0.449 * * *$ & \multirow{3}{*}{ Constant } & $1.156^{* * * *}$ \\
\hline$(0.077)$ & $(0.141)$ & & $(0.199)$ \\
\hline [0.797] & [0.001] & & {$[0.000]$} \\
\hline 140 & 140 & Observations & 140 \\
\hline 0.103 & 0.167 & R-squared & 0.234 \\
\hline 0.084 & 0.122 & Adj. R-squared & 0.189 \\
\hline 5.560 & 18.46 & $\begin{array}{c}\begin{array}{l}\text { F-test/ Wald- } \\
\text { chi2 }\end{array} \\
\end{array}$ & 13.47 \\
\hline 0.001 & 0.000 & Prob $>F$ & 0.000 \\
\hline \multicolumn{4}{|c|}{ Hasman $[\mathrm{P}$-val $]=24.50[0.000] ;$ LM $[\mathrm{P}$-val $]=87.92[0.000]$} \\
\hline & & $\begin{array}{c}\text { Pesaran's CSD } \\
{[\mathrm{P}-\mathrm{val}]}\end{array}$ & $\begin{array}{c}1.183 \\
{[0.237]} \\
\end{array}$ \\
\hline & & Heteros. [P-val] & $0.27[0.613]$ \\
\hline
\end{tabular}

Source: Author's Computation, 2021. Note: ERV represents Exchange rate volatility, FSZ represents Firm Size, and LEV represents the Leverage of the Firms. The dependent variable is ROA representing Return on Asset, Standard errors in parentheses ( ) and $\mathrm{P}$ - values in square brackets [ ]. *** $\mathrm{p}<0.01, * * \mathrm{p}<0.05, * \mathrm{p}<0.1$.

From the result in Table 4, the Breusch and Pagan Lagrangian multiplier (LM) $[\mathrm{Chi} 2=87.92 ; \mathrm{P}$-value $=0.000]$ and Hausman $[\mathrm{Chi} 2=24.50 ; \mathrm{P}$-value $=0.000]$ tests results for the model showed preference for the Fixed Effect Model. Therefore, the Fixed Effect result in column (3) of the Table 4 is interpreted.

The $\mathrm{F}$ - statistics $=13.47 ; \mathrm{P}$-value $=0.000$ in Table 4 indicated that the model was fit meaning that the explanatory variables explain changes in the return on asset (ROA). In addition to this claim, the adjusted R-squared value of 0.189 for the model showed that the independent variables can explain about $18.9 \%$ of variations in the dependent variable. Based on the coefficient of Exchange Rate Volatility (ERV), the results showed that the coefficient of Exchange Rate Volatility (ERV) had a negative and statistically significant effect on return on asset $[$ coefficient $=-0.454 ; \mathrm{P}$-value $=0.013$ ] at $5 \%$ alpha levels. This indicated that ERV had a negative and significant effect on the Return on Asset (ROA) of the selected firms. Alternatively, it means that the Return on Asset (ROA) of the selected firms' increases as exchange rate volatility decreases. Similarly, the coefficient of Firm Size (FSZ) was found to be statistically significant. Specifically, the coefficient was negative and statistically significant at $1 \%$ level [coefficient $=-0.057 ; \mathrm{P}$-value $=0.000$ ] indicating that 
FSZ had a negative and significant effect on the Return on Asset (ROA) of the selected listed firms in Nigeria during the period of this study. The result also revealed that the coefficient of Leverage (LEV) was negative and statistically significant at $10 \%$ level [coefficient $=-0.089 ;$ P-value $=$ 0.091] indicating that LEV too actually had a negative and significant effect on the Return on Asset (ROA) of the firms.

We check whether the residuals (error term) of the estimated model in Table 4 had constant variance and whether the model was free from cross-sectional dependence problem, the study reports heteroskedasticity and Pesaran's CSD tests' result with the null hypothesis of Constant variance and no cross-sectional dependence. From the Table, the test statistics and their associated p-values are statistically insignificant. This means that the residual had constant variances and the model was free from the cross-sectional dependence problem.

Decision: from the results obtained in Table 4, specifically, the results showed that the coefficient of Exchange Rate Volatility (ERV) was negative and statistically significant [coefficient $=-0.454 ;$ P-value $=0.013$ ] at 5\% alpha level. With this result, we have enough proofs against the null hypothesis one $\left[\mathrm{H}_{01}\right]$, which is; "Exchange rate volatility has no significant effect on the return on asset (ROA) of consumer goods firms listed in Nigeria". Therefore, the study concludes that exchange rate volatility had a significant effect on the return on asset (ROA) consumer goods firms listed in Nigeria.

\section{DISCUSSION OF FINDINGS}

The results of the study revealed that exchange rate volatility had a negative statistically significant effect on return on assets. The results are consistent with the result found in prior studies (Kelilume, 2016; Okolo, Ugwuanyi, \& Okpala; BajoRubio, Berke, \& McMillan, 2020; Orji, Ogbuabor, Okeke, \& Anthony-Orji, 2018) found that exchange rate volatility had a negative effect on return on assets consumer and manufacturing firms in Nigeria. The study also is in tandem with the result found in the study of (Musa, 2016) who investigated the effect of foreign exchange rate volatility on the financial performance of local oil marketing companies in Kenya. The outcomes of the study were in accordance with Muchiri (2017) who measured financial performance with return on assets and identified that exchange rate volatility had negative effects on firms' financial performance. A higher exchange rate weakens the currency's value of domestic firms compared to another currency of the foreign firms. In a related study, Ayinde (2014) examined the impact of exchange rate fluctuation on the financial performance of manufacturing companies in Nigeria. The study employed the use of the Generalized Autoregressive Conditional Heteroscedasticity (GARCH) technique coupled with quarterly time series data spanning the period of 1986 to 2012 to investigate the relationship. In line with the theoretical exposition, the results from the study showed that the exchange rate has a negative and significant effect on the return on asset of manufacturing companies in Nigeria.
The findings of this study disagreed with Osano (2016) who observed the existence of a positive relationship between exchange rate volatility and financial performance of listed commercial banks using Return on Assets as a performance indicator. He concluded that a unit increase in debt ratio would result in 0.064 units increase in Return on Asset. Another researcher's work that is not in accordance with the findings of the study is Ishimwen and Ngalawa (2015) who investigated the impact of exchange rate volatility on South Africa's manufacturing exports and financial performance of manufacturing companies in the United States America for the period of 1990Q1 to 2014Q1. Proxied financial performance with return on assets. Their study employed the EGARCH model to measure exchange rate volatility, and the ARDL bounds tests as developed by Pesaran, Shin, and Smith to determine the long-run and short-run effects of exchange rate volatility on the country's manufacturing exports. Their study also carries out a Granger causality test between real exchange rates and exports of manufactured products. The findings of the study showed that an increase in exchange rate volatility had a significant positive effect on the financial performance of manufacturing exports in the long run.

\section{CONCLUSION}

The financial performance of consumer goods companies in Nigeria is constrained by a weak macroeconomic framework with persistent exchange rate fluctuations, multiple exchange rate windows, and forex restrictions and distortionary activities by the central bank. Thus, persistent exchange rate fluctuation exposes the companies to external risks because their projected revenue and costs, alongside profit margin, are affected. Hence this study examined the effect of exchange rate volatility on return on assets of consumer goods manufacturing companies listed in Nigeria. Exchange rate volatile was proxy by the annual exchange rate of naira to dollars, while Firm size and Firm leverages were the control variables. The methodology of the study makes use of an expost facto research design, a purposive sampling technique was used to select a sample size of fourteen (14) consumer goods firms from the listed firms. The study used panel data from 2010 to 2019 while panel regression models estimated were used in place of fixed-effect model and random effect model, while the result of the Hausman test indicated the appropriate between fixed effect model and random effect model. Findings from the empirical results showed that Exchange Rate Volatility had a negative and statistically significant effect on return on assets [coefficient $=-0.454$; Pvalue $=0.013]$ at $5 \%$ significant level. Similarly, Firm's Size was found to be negative and statistically significant to influence Return on assets at $1 \%$ level [coefficient $=-0.057$; P-value $=0.000]$. More so, the result also revealed that Leverage was negative and statistically significant at $10 \%$ level [coefficient $=-0.089 ; \mathrm{P}$-value $=0.091$ ]. The study concluded that exchange rate volatility had a significant effect on the return on asset (ROA) consumer goods firms listed in Nigeria. Based on the findings as exchange rate volatility was 
found to be negatively significant to the financial performance of consumer goods manufacturing companies.

\section{RECOMMENDATION}

From the findings of the study, it is clear that there is evidence in the frequent upsurge of the exchange rate in Nigeria, which has continually devalue the local currency most especially in recent years. Monetary authorities should employ various policies to steer the exchange rate downward. This will help boost local firm return on assets and at the same time increase firms' productivity.

\section{REFERENCES}

[1] Abdul, A., \& Isiaka, T. (2015). Relationship between cost management and profitability: A study of selected manufacturing firms. International Journal of Management Sciences.

[2] Adjei, E. (2019). Exchange rate volatility and economic growth in Ghana. International Journal of Business and Social Science, 10(4), $1-14$

[3] Agubata, S., \& Odubuasi, A. (2018). Effect of exchange rate fluctuation on the financial performance of manufacturing companies in Nigeria. International Journal of Commerce and Management, 4(4), 56-61.

[4] Allayanis, A., Ihuing, I., \& Weston, C. (2016). Foreign currency derivative and firm value. Journal of Finance, 2(2), 56-75.

[5] Amar, D. (2017). Impact of dividend on share pricing in commercial banks of Nepal. Banking Journal, 3(2), 21-55.

[6] Ayinde, T. O. (2014). The impact of exchange rate volatility on manufacturing performance: New Evidence from Nigeria. Fountain Journal of Management and Social Sciences, 3(2), 8392.

[7] Ayobami, O. T. (2019). Exchange rate volatility and the performance of manufacturing sector in Nigeria (1981-2016). African Journal of Economic Review, 7(2), 27-40.

[8] Babalola, A. (2014). Monetary policy and financial performance of manufacturing companies. Journal of Finance and Accounting, 2(3), 87-98

[9] Bajo-Rubio, O., Berke, B. \& McMillan, D. (2020). Exchange rate volatility in the Eurozone. The Open-Access, Open-Assessment EJournal, 14 (5), 1-23.

[10] Bidde, G., Hilary, G., \& Verdi, R. (2009). How financial reporting quality does relate to Investment Efficiency? Journal of Accounting and Economics, 4(8), 112-131.

[11] Casu, B., Girardone, C., \& Molyneux, P. (2006). Introduction to Banking. England: Prentice Hall Press.

[12] Cerra, V., \& Saxena, S. (2010). Contagion and domestic turmoil in Indonesia's currency crisis. Review of International Economics, 2(2), 87-98.

[13] Darell, A., \& West, C. (2018). Philosophy of money and finance. Journal of Finance, 1(2), 76-96.

[14] Ebiringa O. T., \& Anyaogu, C. C. (2014). Analysis of the effect of external reserves management on macroeconomic stability of Nigeria. International Journal of Business Management and Economic Research, 3(6), 646-654.

[15] Hailey, A., Getacher, T. \& Tesfay, H. (2014). Financial performance analysis of commercial banks in Ethiopia. Journal of Business and Economics, 7(2), 67-89.

[16] Harley, T. W. (2018). An empirical investigation of the impact of exchange rate fluctuation on the performance of selected listed firms in Nigeria. Journal of Business Management and Economic Research, 2(3), 1-10.

[17] Ishimwen, A., \& Ngalawa, H. (2015). Exchange rate volatility and manufacturing exports in South Africa. Banks and Bank Systems, 10(3), 29-38.

[18] Kelilume, I. (2016). Exchange rate volatility and firm performance in Nigeria: A dynamic panel regression approach. Proceedings of the Australia-Middle East Conference on Business and Social Sciences, 8(1), 663-665.

[19] Kumar, K. B., Rajan, R. G., \& Zingales, L. (1999). What determines firm size? : National bureau of economic research.

[20] Lagat, C., \& Nyandema, D. (2016). The influence of foreign exchange rate fluctuations on the financial performance of commercial banks listed at the Nairobi Securities Exchange. British Journal of Marketing Studies, 4(3), 1-11.

[21] Mahat, R. F., Dahir, A. M., Sahabuddin, M., \& Mahi, A. S. M. (2017). Exchange rate volatility and financial performance of Agriculture firms in Malaysia: An empirical analysis using GARCH, Wavelet and system GMM. Business and Economic Horizons Journal, 13(3), 409-427.

[22] Majok, E. (2015) Effects of exchange rate fluctuations on the financial performance of Commercial Banks in Kenya. MSc. Thesis.

[23] Moffett, M. H., Stonehill, A. I., \& Eiteman, D. K. (2017). Fundamentals of multinational finance (5th ed.). Chicago, Addison-Wesley, Pearson (The Pearson Series in Finance).

[24] Muchiri, M. (2019). Effect of inflation and interest rates on foreign exchange rates in Kenya. The unpublished project, MBA, Thesis.

[25] Musa, F. M. (2016). The effect of foreign exchange rate volatility on the financial performance of Oil marketing companies in Kenya. MSc. Thesis.

[26] Nwaobia, A. N., Kwarabai, J. D., \& Ogundajo, G. O. (2016). Tax planning and firm value: Empirical evidence from Nigerian consumer goods industrial sector. Research Journal of Finance and Accounting, 7(12), 1-13.

[27] Obisesan, O. G., Ogunsanwo, O. F., \& Akosile, M. O. (2019). Effect of foreign exchange management on economic growth in Nigeria (1987-2017). African Journal of Economic and Sustainable Development, 2(1), 51-65.

[28] Okolo, C. V., Ugwuanyi, O. S., \& Okpala, K. A. (2016). Exchange rate volatility, its determinants, and effects on the manufacturing sector in Nigeria. International Scholarly and Scientific Research \& Innovation, 10(12), 3940-3948.

[29] Orji, A., Ogbuabor, J. E., Okeke, C., \& Anthony-Orji, O. I. (2018). Another side of the Coin: exchange rate movements and the manufacturing sector in Nigeria. Journal of Infrastructure Development, 10(2), 63-79.

[30] Osano, S. A. (2016). Exchange rate volatility and financial performance of listed commercial banks in Kenya. Unpublished $M B A$ project. The University of Nairobi.

[31] Osho, A. E., \& Efuntade, A. O. (2019). Effect of exchange rate fluctuation on the financial performance evaluation of multinational companies in Nigeria. Research Journal of Finance and Accounting, 10(16), 2222-2847.

[32] Osundina, C. K., Osundina J. A., Jayeoba O. O., \& Olayinka I. M. (2016). Exchange rate volatility and banks performance: Evidence from Nigeria. International Journal of Economics and Business Management, 2(4), 1-11.

[33] Oyedokun, T., \& Owolabi, S. (2019). Cost control and profitability of selected manufacturing firms in Nigeria. Journal of Accounting and Strategic Finance, 2(1), 14-33.

[34] Richards, N. D., Simpson, J., \& Evans, J. (2009). International Journal of Economics and Finance, 1(1), 2-22.

[35] Robinson, A., \& Warburton, C. (2005). Empirical evidence of international fisher effect in Bangladesh, India, and China. Journal of Finance, 3(1), 67-74.

[36] Sangosanya, A. O. (2011). Firm growth dynamics in Nigeria's manufacturing industry: A Panel Analysis. Journal of Applied Econometric Review, 1(1), 1-18.

[37] Umeron, A., \& Udo, E. (2015). Working capital management and the performance of selected deposit money banks in Nigeria. British Journal of Advanced Economics, Management, and Trade. 7(1): 23-31.

[38] Zadeh, F. O., \& Eskandari, A. (2012). Firm size as company's characteristic and level of risk disclosure: review on theories and works of literature. International Journal of Business and Social Science, 3(17), 1-16. 